ァントムにより検討した。

[結果】(1) $180^{\circ}, 32$ viewでは， defect 描出能は， Leap, H. R ( 6 角), H. R ( 4 角) の順であり, H. R (4 角) で20〜30秒収集時間で, $1.5 \mathrm{~cm}$ まで描出できた. (2)Bedの影響は，材質がカーボン繊維のため吸収等の影 響はなかった。（3)腕によるImage への影響は，心筋層 が厚く描出され，診断上影響がある. (4)planar像との比 較では, Planar で描出されない $1.5 \mathrm{~cm}$ 以上の defect が描出でき, 病変部の所見を明確化する点で, その有用 性が確認できた。

\section{ECT における検出器の体表面近接運動について} 三重大学医学部附属病院中央放射線部 ○北野外紀雄・前田寿登 東芝・那須工場 掛川 誠・市原 隆

ECT の分解能向上を目的とした検出器の体表面近接 運動による ECT について検討を行なった. 対向型東芝 製 GCA-70 AS ECT 装置を用い，検出器の回転面と垂 直に直径 $1 \mathrm{~mm} の$ 線線源を 7 本, $4 \mathrm{~cm}$ 間隔で平行に, 空気中，水中に配置し，検出器を直径 $45 \mathrm{~cm}$ の円連動 と短軸 $30 \mathrm{~cm}$ ，長軸 $45 \mathrm{~cm}$ のほぼダ円形に近い運動をさ せて，1 投影あたり 10 秒間，4 度毎に 180 度回転させデ 一タ収集した。 また，10〜15 mm の久損のある心筋フ ァントムについても同様に検討した．近接運動は円運動 に比べ，空気中，水中ともFWHM で16\%の改善老認め， 心臓ファントムの ECT 像では久損領惐のコントラスト が向上した. 本法は ECT 像の空間的分解能を向上させ る有效な手段之考えられる.

質問 近接だ円軌道の方法はどうしているか.（座長）

答 実験的に手動ステップで行っている.

質問 ファントムに対し検出器の距離が近くなったり 遠くなったりする場合，感度の影響は？（延沢）

答 あまり関係ないと思われる。

\section{3. 心プールシンチグラフィーによる収縮期左室内圧カ ーブの試作}

名古屋保健衛生大学病院放射線部

○百石 悟・江尻和隆・浅野智子

ニュートンの第 2 法則を応用した Wagner らの計算 式を使用し, 心電図同期心プールシンチグラフィーから 得られた左室 Time-Activity Curveより非観血的に左室 内压を算出する方法を試み Peak pressure, Peak dp/dt, 圧波形について, カテーテル法により得られた結果と比 較検討した。

[結果】Peak Pressure はカテーテル法と比較的よく
一致したが, peak dp/dt は测定範国に問題がありアイ ソトープ法でかなり低值を示した。また，圧波形に関し てはカテーテル法とよく似たパターンを示し, 各種心疾 患における比較では，MI，IHSS，COCM 等で特徴ある パターンを示した。

質問 左室の圧力のする仕事エネルギーが左心室を出 て行く血液の運動エネルギーになると考えてよろしいで しょうか.（座長）

答 今回用いた压計算式は心臓を最あシンプルにモデ ル化したものであるが，大動脈による抵抗は考慮してい ないのですべて血液の運動エネルギーに変わると考える.

44. 心プールのゲート収集条件設定について

県西部浜松医療センター

○延沢秀二・松原 忍・竹山正信 河 相吉・小林 聡

心電同期収集により心機能解析する場合, 収集条件が 解析結果によ゙のような影響をおよぼすか検討を加えた。

1）LV curve およびEF 值に関しては, R-R 間の Frame 数が最も関与し，Frame 数を少なくすると EF 值及び LV 容積変化率共に低值を示した。

2) REF 及び amplitude image において影響が認めら れたのは, matrix size および frame 数で共に少なくす るほよ゙心機能を過小評洒する傾向を示した。

3) Phase image においては matirix size および frame 数を少なくする位相異常部が小さく表示される 傾向を示し R-R 間の収集割合は最む大きく影響し，正 確な位相解析ができなくなるととが確認された。

45. 第 1 回循環時法による肝動脈, 門脈成分定量評価法 の基礎理論の検討と肝血流ファンクショナルイメー ジの作成

富山医科薬科大学附属病院

○安井正一・利波修一 稻垣晶一・水木敏雄

肝動脈，門脈成分定量評洒法，および一回循環時間内 の放射性薬剂の残留率の基礎的検討と門脈血流を表わす ファンクショナルイメージの作成を目的とする.

99m TC スズコロイドを使用した第 1 回循環時法のため 然時間に行うことができ，さらに簡便であり再現性む高 い検查法であるといえる，特にび慢性肝疾患の経過観察 には有用であると思われる。理論形成上の問題点となる 肝提取率は，肝内残留が長く，ここで問題とする左心室 第二ピークまでの肝内停帯率が $90 \%$ 以上と考えられ算出 法として妥当であると言える。乙れらに加えファンクシ ヨナルイメージにより肝血流比の局所的な観察が可能と 
なった。

\section{6. 臨床核医学領域における画像散乱線除去処理 (Sca t-} taring subtraction）の検討

\section{富山医科蒋科大学附属病院 \\ ○安井正一・利波修一 \\ 稻垣晶一・水木敏雄}

一般には目的とする光電ピーク画像のみを収集してい るが散乱線領域で画像を収集し本来の画像から散乱線成 分を除去することで，より鮮鋭で絶対カウント比の正し い画像を抽出できる.

(1)二核種混合核種に扝ける低エネルギー核種像の抽 出.

(2)低エネルギー高分解コリメータにおける高低混合エ ネルギー核種の撮像.

(3)単一エネルギー核種における散乱線成分の除去.

上記について検討した結果，いずれもが有效な結果を おさめ 2 ピークデータ収集装置と核医学用コンピュータ の使用法として有用であり, 高解像度の画像之絶対カウ ント比が正しく定量的洒値の高い画像が得られる。

\section{座長集約}

演題40〜42は SPECT 亿関する報告である.

演題40はアームやへッドの傾きが再構成画像におよぼ す影響を 3 次元的広がりをすつフラインソースファント ムを製作して line spread function の再機成の程度か らカメラの傾きを補正すると報告した.

演題41は収集角度およびカウントが分解能に寄与する 要因を心藏ファントムを用いて報告した。

演題42は $\gamma$ カメラの回転軌道を体表面に近接（だ円軌 道）させることにより分解能を向上させることができる と報告した。

ECT では画質はrカメラの性能でほぼ決まると言わ れており, 機械的なズレ, 回転軸のズレ等により画質低 下を招くことのない日でろの保守管理が必要である.

演題43は心プールのゲートイメージから収縮期の左室 内圧を求めるととができると報告した。

アイソトープでは通常圧情報を得るととはできないが， 左心室をモデル化して左心室圧のする仕事エネルギーは 左心室を出る血液の運動エネルギーに保存されるとして ベルヌーイの定理とニュートンの第 2 法則を応用して左 心室圧を求めていた. ゲートイメージのボリュームカー ブを 2 度微分して使用するため最初のゲート収集条件の 変化による影響等も検討してほしい. 非観血的な方法な ので今後の研究を期待したい.

演題44は心プールのゲート収集条件について報告し
た.

1 ピクセル単位の画像を機能イメージとして扱うファ ンクショナルイメージの条件設定が全体の収集条件を決 定すると思われる。

演題45は門脈成分定量評価法について報告した。

肝循環動態の把握はびまん性, 限局性の各種疾患の微 妙な変化をとらえる上で重要であり, 肝細胞棏築等の変 化をみる上で肝血流の定量評洒法は早く確立されなれな ければならないだろうと思われる。

演題46は散乱線画像処理についてである.

二つの核種が混在して体内にあるとき低エネルギー核 種の画像はバックを多く含むが, バックグラウンドを低 エネルギ一核種のピーク近くに近似的に設定してサブト ラクションすることにより低ェネルギー核種のピークを とり出せると報告した.

この方法はエネルギーの異なるすのどうしのサブトラ クションであるため, 体厚の変化にともなう補正等さら に慎重な検討を願いたい。

RI-2

座長 河村信夫（名古屋第一赤十字病院）

\section{Platelet factor 4（PF4）測定の基礎的検討}

大垣市民病院放射線科特殊放射線センター ○矢橋俊丈・松尾定雄・吉田 宏 馬場健碩・奥村恭已・遠藤斗紀雄 安田鋭介・正田 稔・金森勇雄

今回われわれは PF4（血小板第四因子）測定キット （PF4・RIA・kit）を使用する機会を得，基礎的検討を行 ったので，その結果について報告する。

〔結果】 (1) sample の調整は採血・採血後遠心分離す るまでの処置および遠心分離条件などの一連の操作は正 確かつ迅速に行なわわれる必要があると考えられた。 (2)再現性，回収率及び希釈試験は良好であった。(3) incubation 条件は室温・120分で良いと考えられた。 (4) PF4 值と $\beta$-TG 值との相関は, $\gamma=0.846(\mathrm{P}<0.01, n=$ $75 ）$ と有意な相関を得た。(5)正常人 $(n=42)$ における PF4 值は M. V. \pm 2 S. D. $=11.7 \pm 8.5 \mathrm{ng} / \mathrm{ml}$ であった. 以上の如く, 手法は他の RIA キット同様日常の検查に 充分活用し得るキットであると考える。

48. Micro-sephalose 法による血中インスリン測定法検 討

国立名古屋病院放射線科

○梅村 実・中条正雄 長谷川みち代・上田 修 内科医 新実光朗 